\title{
OGÓLNOKRAJOWE ORGANIZACJE JEDNOSTEK SAMORZĄDU TERYTORIALNEGO - MIĘDZY LOBBINGIEM A DORADZTWEM
}

\section{BETWEEN LOBBING AND ADVISORY - LOCAL GOVERNMENT ASSOCIATIONS IN POLAND}

\begin{abstract}
Streszczenie
Kluczową rolę w relacja rządowo-samorządowych odgrywają ogólnopolskie organizacje samorządowe, które stanowią reprezentację strony samorządowej w Komisji Wspólnej Rządu i Samorządu Terytorialnego. Celem artykułu jest przedstawienie zasobów organizacyjnych organizacji samorządowych, przedmiotu i sposobu ich działań, a także możliwości kształtowania samorządowej agendy politycznej.
\end{abstract}

Słowa kluczowe: samorząd terytorialny; relacje rządowo-samorządowe; organizacje samorządowe; polityka publiczna.

\begin{abstract}
Central-local government relations are driven by local government associations, which represent local and regional entities in Central-Local Government Common Commission. The aim of this article is to examine what kind of resources local government associations have; how they are running and to answer the question whether they have possibility to create political agenda or not.
\end{abstract}

Keywords: local government; central-local government relations; local government associations; public policy. 


\section{Wprowadzenie}

Obowiązującym obecnie paradygmatem zarządzania publicznego jest podejście sieciowe, nazywane w języku angielskim pojęciem governance. Jak zauważyła L. Rajca: ,Jest to efekt w części w wyniku krytyki nowego zarządzania publicznego, a w części jako niemal globalny trend w kierunku ponownego skoncentrowania uwagi na rolę społeczeństwa obywatelskiego w realizowaniu celów publicznych"1. Cały czas trwa w nauce spór co do znaczenia samego terminu governance. Zdaniem niektórych badaczy wieloznaczność tego terminu zdaje się pogłębiać. Jak zauważa J. Sroka, w literaturze przedmiotu można znaleźć aż dziewięć odmiennych sposobów rozumienia pojęcia governance: (1) państwo minimum (minimal state); (2) kierowanie korporacyjne (corporate governance); (3) nowe zarządzanie publiczne (New public management); (4) dobre rządzenie (good governance); (5) systemy cybernetyczno-społeczne (social-cybernetic systems); (6) samoorganizujące się układy sieciowe (self-organised networks); (7) wielopoziomowe rządzenie wielopasmowe (multilevel network governance); (8) koordynacji w obrębie sieci powstających między podmiotami gospodarczymi (inter-firm governance); (9) zewnętrznej oraz wewnętrznej koordynacji układów sieciowych (governance in and by networks) $)^{2}$. W literaturze przedmiotu jest jednak zgodność co do tego, że paradygmat współzarządzania governance nie zwraca uwagi na kwestie funkcjonowania podmiotów państwowych i instytucji jako najważniejszych graczy politycznych. Podkreśla się z kolei znaczenie sieci, współzarządzania, międzyorganizacyjnej współpracy, a także zaufania i współzależności łączącej państwo i społeczeństwo ${ }^{3}$. Na potrzeby niniejszego artykułu będę posługiwał się pojęciem governance współzarządzanie w rozumieniu wielopoziomowego rządzenia, w którym zaangażowane w proces realizacji polityk publicznych są nie tylko podmioty administracji rządowej, ale także jednostki samorządu terytorialnego, które odpowiadają za praktyczną realizację przekazanych lub powierzonych im zadań. Współzarządzanie rozumiane w ten sposób wymaga zatem zaangażowania obu stron, zaufania oraz dobrowolności. Współrządzenie

$1 \quad$ L. Rajca, Reformy inspirowane koncepcja wspótrzadzenia (governance) w Anglii, [w:]

D. Plecka (red.), Wspótczesne wyzwania administracji rządowej i samorzq̨owej, Toruń 2013, s. 367.

2 J. Sroka, Deliberacja i rzqdzenie wielopasmowe. Teoria i praktyka, Wrocław 2009, s. 45-46.

3 A. Mette Kjær, Governance, Polity Press, Cambridge 2004, s. 4. 
opiera się na negocjacjach dla osiągnięcia konsensu i wzajemnego zrozumienia. Wymaga wielu form partycypacji, jak również różnorodności uczestników procesu współrządzenia ${ }^{4}$. Osiągnięcie takich relacji możliwe jest do osiągnięcia za pomocą wykorzystania narzędzi prawnych oraz potencjału organizacyjnego, które buduje względną równowagę stron. Analizując obowiązujące narzędzia prawne, stwarzające przestrzeń do relacji rządowo-samorządowych należy wskazać w pierwszej kolejności funkcjonowanie Komisji Wspólnej Rządu i Samorządu Terytorialnego, która jest organem doradczym Rady Ministrów $\mathrm{w}$ zakresie koordynowania relacji rządowo-samorządowych oraz zgodnie z art. 2 ustawy jest forum wypracowywania wspólnego stanowiska Rządu i samorządu terytorialnego ${ }^{5}$. Na podstawie obowiązujących regulacji prawnych można stwierdzić, że zapewnia ona stały udział przedstawicielom jednostek samorządu terytorialnego $\mathrm{w}$ rządowy proces legislacyjny i monitorowania $\mathrm{w}$ ten sposób inicjatyw Rady Ministrów, które dotyczą funkcjonowania jednostek samorządu terytorialnego ${ }^{6}$. Przedmiotem niniejszego artykułu jest spojrzenie na relacje rządowo-samorządowe z perspektywy potencjału organizacyjnego organizacji samorządowych, które reprezentują stronę samorządową w ramach prac Komisji Wspólnej Rządu i Samorządu Terytorialnego. Zgodnie z rozporządzeniem Rady Ministrów jest to sześć organizacji reprezentujących gminy liczące powyżej 300 tys. mieszkańców, gminy posiadające status miast, gminy, których siedziby władz znajdują się w miastach położonych na terytorium tych gmin, organizacja reprezentująca jednostki samorządu powiatowego oraz jednostki samorządu województwa. Są to obecnie odpowiednio: Unia Metropolii Polskich, Związek Miast Polskich, Unia Miasteczek Polskich, Związek Gmin Wiejskich RP, Związek Powiatów Polskich oraz Związek Województw RP7 . Relacje rządowo-samorządowe na nowo powrócił do debaty publicznej, a przez to i do refleksji naukowej w związku z negatywnymi skutkami prywatyzacji

$4 \quad$ L. Rajca, Reformy inspirowane..., s. 368.

5 Ustawa z dnia 6 maja 2005 r. o Komisji Wspólnej Rządu i Samorządu Terytorialnego oraz o przedstawicielach Rzeczypospolitej Polskiej w Komitecie Regionów Unii Europejskiej, Dz.U. Nr 90, poz. 759 ze zm.

6 Więcej na temat Komisji Wspólnej Rządu i Samorządu Terytorialnego zob. R. Gawłowski, Komisja Wspólna Rzadu i Samorzadu Terytorialnego - od konsultacji do współudziału w rządowym procesie legislacyjnym, Samorząd Terytorialny 2015, nr 12, s. 5-15.

7 Rozporządzenie Rady Ministrów z dnia 29 stycznia 2008 r. w sprawie określenia ogólnopolskich organizacji jednostek samorządu terytorialnego, które są uprawnione do wyznaczania przedstawicieli do Komisji Wspólnej Rządu i Samorządu Terytorialnego, Dz.U. Nr 15, poz. 97. 
zadań publicznych. Jak zauważyła J. Morphet zrozumiano wówczas, że skuteczne zarządzanie publiczne i realizacja zadań publicznych przez jednostki samorządu terytorialnego musi być rozumiane wyłącznie w połączeniu z administracją rządową. Reforma administracji samorządowej ma tylko wówczas sens jeśli towarzyszy jej reforma administracji rządowej ${ }^{8}$. Problemem badawczym niniejszego artykułu będzie kwestia potencjału organizacyjnego organizacji samorządowych do kształtowania relacji rządowo-samorządowych. Jego rozwiązanie będzie możliwe dzięki odpowiedzi na pytania: ile jednostek samorządu terytorialnego należy do ogólnopolskich organizacji samorządowych? Jaki jest potencjał finansowy, kadrowy oraz merytorycznych tychże organizacji? Czy maja one potencjał do kształtowania agendy politycznej? Czy organizacje samorządowe są podmiotami, które samodzielnie formułują określone interesy polityczne i dlatego określa się je swoistym systemem interesów, czy starają się występować w formie pośredników interesów politycznych, ogniw, poprzez które ,zewnętrzne” interesy sekcjonalne próbują uzyskać dojście do procesu decyzyjnego (wpływ na treść decyzji). Kategorią politologiczną za pomocą której będę starał się odpowiedzieć na powyżej postawione pytania jest kategoria grup interesu.

\section{Ogólnopolskie organizacje samorządowe jako grupy interesu}

Interes to świadome dążenie jednostki lub grupy do realizacji określonego celu'. Dzięki takiemu sposobowi rozumienia interesu grupy interesu można określić jako podmioty pośredniczące w procesie artykulacji i reprezentacji interesów politycznych mające statut dobrowolnych stowarzyszeń (organizacji), w więc takich, których przetrwanie oparte jest na tzw. dobrowolnej partycypacji. Oznacza to, iż oferują one w sposób mniej lub bardziej widoczny określone zachęty czy korzyści dla swych członków, a niekiedy i sympatyków ${ }^{10}$.

Oczywiście wcale nie musi chodzić o ,realne” korzyści i niekiedy wystarczy deklaracja czy też przyrzeczenie ich osiągnięcia w przyszłości. Te zachęty czy korzyści można określić mianem zasobów politycznych, których dystrybucja albo tylko przyrzeczenie dystrybucji wywołują efekt w postaci

J. Morphet, Modern Local Government, California 2008, s. 5.

9 R. Herbut, Interes polityczny - proces instytucjonalizacji grup interesu oraz jej modele, [w:] B. Szmulik, M. Żmigrodzki (red.), Wprowadzenie do nauki o państwie i polityce, Lublin 2007, s. 380.

10 Tamże, s. 385. 
dobrowolnej partycypacji. Mamy więc w tym momencie do czynienia z próbą wskazania na motywy działania jednostkowego, uzasadniające chęć przynależności do organizacji. Jakie korzyści są możliwe do osiągnięcia przez przynależność jednostek samorządu terytorialnego w ogólnopolskich organizacjach samorządowych? Po pierwsze, jest to możliwość dostępu do wiedzy na temat sposobów zarządzania usługami publicznymi przez pozostałych członków organizacji, bądź poprzez zamawiane ekspertyzy i opinie. Po drugie, jest to możliwość współuczestniczenia w rządowym procesie legislacyjnym, bądź procesie stanowienia prawa przez parlament w związku z aktywnym opiniowaniem projektów aktów prawnych. Po trzecie wreszcie, jest to możliwość rozwinięcia współpracy międzynarodowej z jednostkami samorządu terytorialnego z innych krajów, z którymi współpracuje dana organizacja samorządowa. Analiza potencjału wybranych ogólnopolskich organizacji samorządowych zostanie dokonana na podstawie klasyfikacji grup interesów zaproponowanej przez R. Herbuta, który wyróżnił w ramach swojej klasyfikacji takie zagadnienia jak: (1) poziom rozwoju struktur wewnętrznych; (2) metody działania; (3) zakres promowanych kwestii problemowych; (4) trwałość oraz (5) sposób powiązania z polityką publiczną państwa. Wskazane kryteria uwzględniają zarówno elementy wewnętrzne funkcjonowania organizacji, jak i realną możliwość oddziaływania na agendę polityczną państwa. W związku z powyższym dają możliwość wszechstronnej oceny działania organizacji samorządowych. W ramach badania zasobów organizacji, tj. ich siły przetargowej, a więc zdolność do efektywnego promowania i reprezentowania określonych interesów politycznych, można wskazać na takie elementy jak: (1) dojście do strategicznych ośrodków władzy, odpowiedzialnych za przebieg procesu legislacyjnego - układ osobistych i instytucjonalnych powiązań z partami politycznymi oraz instytucjami państwa; (2) zasoby finansowe i organizacyjne - które pozwalają wprost oddziaływać na ośrodki decyzyjne; (3) zasoby fachowego i profesjonalnego przygotowania-możliwość przygotowywania fachowych opracowań i ekspertyz, które służą następnie jako element debaty publicznej i na końcu (4) poparcie opinii publicznej dla grup interesu i promowanych przez nią celów - jako element legitymizacji podejmowanych działań, mobilizacji społecznej. To one w dużym stopniu determinują charakter podejmowanych działań taktycznych oraz wyznaczają możliwości budowania i stosowania strategii politycznych. To one także określają możliwości wpływania na podmioty administracji rządowej i rządowy proces legislacyjny. Do odpowiedzi na pytania 
badawcze wykorzystałem regulaminy organizacyjne ogólnopolskich organizacji samorządowych ${ }^{11}$, roczne sprawozdania $\mathrm{z}$ ich funkcjonowania, a także informacje zawarte na stronie internetowej organizacji ${ }^{12}$. Wskazane źródła były analizowane pod kątem metod działania organizacji, poziomu rozwoju struktur wewnętrznych, zakresu działania, sposobu powiązania z politykami publicznymi, a także trwałości organizacji. Uzyskane informacje przedstawione są w poniższej tabeli.

Tabela 1. Zestawienie zasobów ogólnopolskich organizacji samorządowych.

\begin{tabular}{|c|c|c|c|c|c|c|}
\hline & $\begin{array}{l}\text { Związek Miast } \\
\text { Polskich }\end{array}$ & $\begin{array}{c}\text { Unia Metropolii } \\
\text { Polskich }\end{array}$ & $\begin{array}{l}\text { Unia Miaste- } \\
\text { czek Polskich }\end{array}$ & $\begin{array}{l}\text { Związek Woje- } \\
\text { wództw RP }\end{array}$ & $\begin{array}{c}\text { Związek } \\
\text { Powiatów } \\
\text { Polskich }\end{array}$ & $\begin{array}{c}\text { Związek } \\
\text { Gmin } \\
\text { Wiejskich } \\
\text { RP }\end{array}$ \\
\hline $\begin{array}{l}\text { Poziom } \\
\text { rozwoju } \\
\text { struktur } \\
\text { we- } \\
\text { wnętrz- } \\
\text { nych } \\
\text { (poza } \\
\text { ciałami } \\
\text { statuto- } \\
\text { wymi) }\end{array}$ & $\begin{array}{l}\text { Dyrekcja (4 os.); } \\
\text { Informacja i PR(4 } \\
\text { os.); Samodzielne } \\
\text { stanowisko ( } 2 \text { os.); } \\
\text { Analityczno-badawczy } \\
\text { ( } 5 \text { os.); Administracyjne } \\
\text { (7 os.); Zagraniczne } \\
\text { ( } 6 \text { os.) - } 294 \text { miast na } \\
\text { kwiecién } 2016-72 \% \\
\text { ludności miejskiej } \\
\text { Polski; } 16 \text { komisji } \\
\text { problemowych. }\end{array}$ & $\begin{array}{l}12 \text { komisji } \\
\text { problemowych; } 5 \\
\text { zespołów doraź- } \\
\text { nych; } 9 \text { os. }\end{array}$ & $\begin{array}{l}\text { Brak danych } \\
\text { na temat liczby } \\
\text { zatrudnio- } \\
\text { nych osób; } 17 \\
\text { miasteczek. }\end{array}$ & $\begin{array}{l}8 \text { Komisji, } 7 \text { Ze- } \\
\text { społów, } 10 \text { os. }\end{array}$ & $\begin{array}{l}\text { Brak } \\
\text { danych } \\
\text { na temat } \\
\text { liczby } \\
\text { zatrud- } \\
\text { nionych } \\
\text { osób; } 16 \\
\text { kon- } \\
\text { wentów } \\
\text { powia- } \\
\text { towych } \\
\text { (działania } \\
\text { dorad- } \\
\text { cze); 315 } \\
\text { powiatów, } \\
\text { komisje } \\
\text { problemo- } \\
\text { we. }\end{array}$ & $\begin{array}{l}9 \text { os. } / \mathrm{na} \\
29.05 .2016 \\
-591 \text { gmin } \\
\text { wiejskich. }\end{array}$ \\
\hline
\end{tabular}

11 Statut Unii Metropolii Polskich przyjęty na podstawie uchwały Rady Fundacji UMP z dnia 8 grudnia 2005 r.; Statut Związku Miast Polskich przyjęty 19 stycznia 1991 r. przez Kongres Restytucyjny w Poznaniu, Statut Unii Miasteczek Polskich przyjęty w dniu 2 kwietnia 2012 r.; Statut Związku Gmin Wiejskich RP uchwalony jako tekst jednolity podczas XXVI Zgromadzenia Ogólnego ZGW RP 10 maja 2012 r. w Poznaniu; Statut Związku Powiatów Polskich z dnia 27 lutego 1999 r.; Statut Związku Województw RP z dnia 13 lutego 2002 r.

12 Strona internetowa Unii Metropolii Polskich www.metropolie.pl; strona internetowa Związku Miast Polskich www.zmp.poznan.pl; strona internetowa Unii Miasteczek Polskich www.ump.home.pl; strona internetowa Związku Gmin Wiejskich RP www.zgwrp.pl; strona internetowa Związku Powiatów Polskich www.zpp.pl; strona internetowa Związku Województw RP www.zwrp.pl. 


\begin{tabular}{|c|c|c|c|c|c|c|}
\hline $\begin{array}{l}\text { Metody } \\
\text { dzialania }\end{array}$ & $\begin{array}{l}\text { System Analiz Samo- } \\
\text { rządowych; Projekty } \\
\text { Norweskie; Samorząd } \\
\text { Miejski; lobbing } \\
\text { legislacyjny; Stawka } \\
\text { większa niż } 8 \text { mld.; } \\
\text { wymiana doświad- } \\
\text { czeń w zarządzaniu } \\
\text { miastami; współpraca } \\
\text { międzynarodowa } \\
\text { (polsko-norweska } \\
\text { i polsko-francuska); } \\
\text { MSZ pomoc Ukrainie; } \\
\text { Ukraina, Mołdawia, } \\
\text { Gruzja. }\end{array}$ & 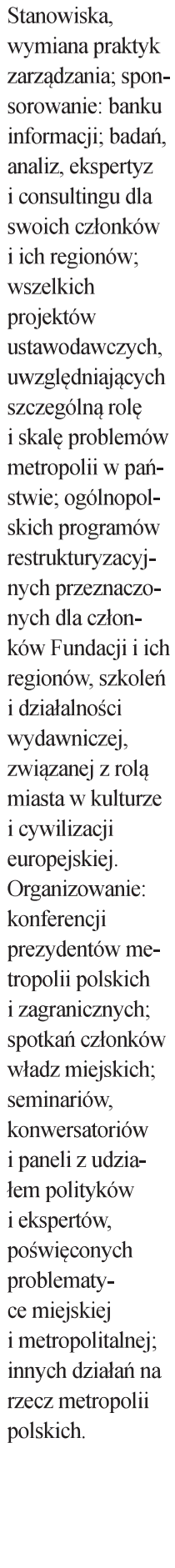 & $\begin{array}{l}\text { Unia realizuje } \\
\text { swoje cele } \\
\text { przede wszyst- } \\
\text { kim poprzez: } \\
\text { promocję i wdra- } \\
\text { żanie lokalnych } \\
\text { inicjatyw } \\
\text { kulturowych, } \\
\text { gospodarczych } \\
\text { i ekologicznych; } \\
\text { prowadzenie } \\
\text { działalności } \\
\text { informacyjnej } \\
\text { i wydawniczej; } \\
\text { organizowanie } \\
\text { działalności } \\
\text { badawczej } \\
\text { i szkoleniowej } \\
\text { o tematyce } \\
\text { związanej z re- } \\
\text { alizacją celów } \\
\text { Unii; współpraca } \\
\text { z pokrewnymi } \\
\text { organizacjami } \\
\text { krajowymi } \\
\text { i zagranicznymi. }\end{array}$ & $\begin{array}{l}\text { Reprezentowa- } \\
\text { nie interesów } \\
\text { województw na } \\
\text { forum krajowym } \\
\text { i międzynarodo- } \\
\text {-wym; } \\
\text { podejmowanie } \\
\text { inicjatyw w celu } \\
\text { decentralizacji } \\
\text { uprawnień, } \\
\text { w tym finansów } \\
\text { na rzecz samo- } \\
\text { rządów i ich } \\
\text { efektywnego } \\
\text { wykorzystania } \\
\text { dla rozwoju } \\
\text { regionów; } \\
\text { inicjowanie } \\
\text { i opiniowanie } \\
\text { projektów aktów } \\
\text { prawnych, } \\
\text { dotyczących } \\
\text { samorządu } \\
\text { terytorialnego; } \\
\text { wymiana } \\
\text { doświadczeń } \\
\text { w zakresie } \\
\text { zadań własnych } \\
\text { województw } \\
\text { i zadań z zakresu } \\
\text { administracji } \\
\text { rządowej, } \\
\text { inspirowanie } \\
\text { i podejmowanie } \\
\text { wspólnych } \\
\text { inicjatyw; } \\
\text { nawiązywanie } \\
\text { kontaktów } \\
\text { zagranicznych; } \\
\text { prowadze- } \\
\text { nie pracy } \\
\text { informacyjnej, } \\
\text { konsultacyjnej } \\
\text { i programowej. }\end{array}$ & $\begin{array}{l}\text { Reprezen- } \\
\text { towanie } \\
\text { powiatów } \\
\text { na forum } \\
\text { międzyna- } \\
\text { rodowym; } \\
\text { inicjowa- } \\
\text { nie i opi- } \\
\text { niowanie } \\
\text { aktów } \\
\text { prawnych, } \\
\text { propa- } \\
\text { gowanie } \\
\text { wymiany } \\
\text { doświad- } \\
\text { czeń } \\
\text { w zakresie } \\
\text { wykony- } \\
\text { wanych } \\
\text { zadań; } \\
\text { inspiro- } \\
\text { wanie } \\
\text { i podej- } \\
\text { mowanie } \\
\text { wspól- } \\
\text { nych } \\
\text { inicjatyw, } \\
\text { praca } \\
\text { informa- } \\
\text { cyjna, } \\
\text { konsul- } \\
\text { tacyjna } \\
\text { i progra- } \\
\text { mowa, } \\
\text { działal- } \\
\text { ność wy- } \\
\text { dawnicza, } \\
\text { now, dele- } \\
\text { do } \\
\text { instytucji, } \\
\text { działania } \\
\text { z organa- } \\
\text { mi admi- } \\
\text { imprananie } \\
\text { kultural- } \\
\text { nych. } \\
\text { nubicz- } \\
\text { nojie }\end{array}$ & $\begin{array}{l}\text { Realizacja } \\
\text { projektów } \\
\text { szkole- } \\
\text { niowych, } \\
\text { badania } \\
\text { wewnątrz } \\
\text { związku } \\
\text { dotyczące } \\
\text { działań } \\
\text { inwesty- } \\
\text { cyjnych, } \\
\text { szkolenia } \\
\text { dla urzęd- } \\
\text { ników } \\
\text { gminnych, } \\
\text { stanowiska } \\
\text { wobec } \\
\text { projektów } \\
\text { ustaw. }\end{array}$ \\
\hline
\end{tabular}




\begin{tabular}{|c|c|c|c|c|c|c|}
\hline $\begin{array}{l}\text { Zakres } \\
\text { promo- } \\
\text { wanie } \\
\text { kwestii } \\
\text { proble- } \\
\text { mowych }\end{array}$ & $\begin{array}{l}\text { Reprezentowanie } \\
\text { miast we wszystkich } \\
\text { wspólnych sprawach } \\
\text { na forum krajowym } \\
\text { i międzynarodowym; } \\
\text { inicjowanie i opi- } \\
\text { niowanie projektów } \\
\text { aktów prawnych, } \\
\text { dotyczących samorzą- } \\
\text { dów terytorialnych; } \\
\text { propagowanie wymiany } \\
\text { doświadczeń w zakresie } \\
\text { wykonywanych zadań } \\
\text { własnych miast i zadań } \\
\text { im zleconych przez } \\
\text { administrację rządową; } \\
\text { inspirowanie i podej- } \\
\text { mowanie wspólnych } \\
\text { inicjatyw gospodar- } \\
\text { czych, mających } \\
\text { wpływ na rozwój } \\
\text { i bogacenie się miast } \\
\text { polskich; prowadzenie } \\
\text { pracy informacyjnej, } \\
\text { konsultacyjnej i progra- } \\
\text { mowej, mającej na celu } \\
\text { wspólne rozwiązywanie } \\
\text { problemów w zakresie } \\
\text { poszczególnych } \\
\text { dziedzin działalności } \\
\text { samorządu miejskiego, } \\
\text { prowadzenie działalno- } \\
\text { ści wydawniczej, szko- } \\
\text { leniowej i promocyjnej, } \\
\text { dotyczącej } \\
\text { problematyki Związku } \\
\text { i jego członków. }\end{array}$ & $\begin{array}{l}\text { Wspieranie roz- } \\
\text { woju samorząd- } \\
\text { ności terytorialnej } \\
\text { i gospodarczej; } \\
\text { tworzenie pod- } \\
\text { staw kształ- } \\
\text { towania się } \\
\text { społeczeństwa } \\
\text { obywatelskie- } \\
\text { go; promocja } \\
\text { inicjatyw i działań } \\
\text { związanych } \\
\text { z tworzeniem } \\
\text { i funkcjonowa- } \\
\text { niem struktur } \\
\text { regionalnych i lo- } \\
\text { kalnych; wspólne } \\
\text { rozwiązywanie } \\
\text { specyficznych } \\
\text { problemów } \\
\text { wielkich miast; } \\
\text { współpraca z or- } \\
\text { ganami państwa } \\
\text { oraz organizacja- } \\
\text { mi ogólnopolski- } \\
\text { mi, zagranicznymi } \\
\text { i międzynarodo- } \\
\text { wymi dla zwięk- } \\
\text { szenia roli metro- } \\
\text { polii w państwie } \\
\text { i integracji } \\
\text { europejskiej. }\end{array}$ & $\begin{array}{l}\text { Obrona wspól- } \\
\text { nych interesów } \\
\text { jej członków; } \\
\text { wspieranie idei } \\
\text { samorządności } \\
\text { lokalnej; współ- } \\
\text { działanie gmin } \\
\text { zmierzających } \\
\text { do rewitalizacji } \\
\text { historycznych } \\
\text { miasteczek } \\
\text { polskich i kre- } \\
\text { owania nowych; } \\
\text { podejmowanie } \\
\text { działań przyczy- } \\
\text { niających się do } \\
\text { gospodarczego } \\
\text { i kulturowego } \\
\text { rozwoju gmin } \\
\text { - miasteczek. }\end{array}$ & $\begin{array}{l}\text { Problematyka } \\
\text { decentraliza- } \\
\text { cji władzy, } \\
\text { efektywne } \\
\text { wykorzystanie } \\
\text { zasobów na } \\
\text { rzecz rozwoju, } \\
\text { prace legislacyj- } \\
\text { ne, tworzenie } \\
\text { tożsamości re- } \\
\text { gionalnej, dzia- } \\
\text { łalność naukowa } \\
\text { i analityczna. }\end{array}$ & $\begin{array}{l}\text { Celem } \\
\text { związ- } \\
\text { ku jest } \\
\text { wspiera- } \\
\text { nie idei } \\
\text { samorza- } \\
\text { du, inte- } \\
\text { growanie } \\
\text { i obrona } \\
\text { interesów } \\
\text { powiatów, } \\
\text { kształ- } \\
\text { towanie } \\
\text { wspólnej } \\
\text { polityki, } \\
\text { wspie- } \\
\text { ranie } \\
\text { inicjatyw } \\
\text { na rzecz } \\
\text { rozwoju } \\
\text { i promocji } \\
\text { powiatów, } \\
\text { wymiana } \\
\text { doświad- } \\
\text { czeń oraz } \\
\text { upo- } \\
\text { wszech- } \\
\text { nienia } \\
\text { mode- } \\
\text { lowych } \\
\text { rozwiązań } \\
\text { w zakresie } \\
\text { rozwoju } \\
\text { i zarzą- } \\
\text { dzania } \\
\text { w powia- } \\
\text { tach; pro- } \\
\text { wadzenie } \\
\text { działań } \\
\text { nauko- } \\
\text { wych. }\end{array}$ & $\begin{array}{l}\text { Wspieranie } \\
\text { idei samo- } \\
\text { rządności } \\
\text { terytorial- } \\
\text { nej, obrona } \\
\text { interesów } \\
\text { gmin } \\
\text { wiejskich, } \\
\text { dążenie do } \\
\text { rozwoju } \\
\text { i wspiera- } \\
\text { nie dzia- } \\
\text { talności } \\
\text { naukowej, } \\
\text { sportowej, } \\
\text { oświa- } \\
\text { towej, } \\
\text { kulturalnej. }\end{array}$ \\
\hline $\begin{array}{l}\text { Trwałość } \\
\text { (rok } \\
\text { powsta- } \\
\text { nia) }\end{array}$ & 1991 & 1990 & 1990 & 2002 & 1999 & 1993 \\
\hline
\end{tabular}




\begin{tabular}{|c|c|c|c|c|c|c|}
\hline $\begin{array}{l}\text { Sposób } \\
\text { powiąza- } \\
\text { nia z po- } \\
\text { litykami } \\
\text { publicz- } \\
\text { nymi } \\
\text { (czynny } \\
\text { udzial } \\
\text { w pra- } \\
\text { cach in- } \\
\text { stytucji } \\
\text { publicz- } \\
\text { nych) }\end{array}$ & $\begin{array}{l}\text { Komisja Wspólna } \\
\text { Rządu i Samorządu } \\
\text { Terytorialnego, Komitet } \\
\text { Regionów, Kongres } \\
\text { Władz Lokalnych i Re- } \\
\text { gionalnych, Projekty } \\
\text { ministerialne, Wspól- } \\
\text { praca zagraniczna }\end{array}$ & $\begin{array}{l}\text { Komisja Wspólna } \\
\text { Rządu i Samo- } \\
\text { rządu Terytorial- } \\
\text { nego, Kongres } \\
\text { Władz Lokalnych } \\
\text { i Regionalnych } \\
\text { CLRAE, Komitet } \\
\text { Regionów, Komi- } \\
\text { sja Trójstronna; } \\
\text { Komisja } \\
\text { Heraldyczna }\end{array}$ & $\begin{array}{l}\text { Komisje } \\
\text { Sejmowe i Se- } \\
\text { nackie, Komisja } \\
\text { Trójstronnej } \\
\text { ds. Społeczno- } \\
\text {-Gospodarczych, } \\
\text { Komisji } \\
\text { Wspólnej Rządu } \\
\text { i Samorządu } \\
\text { Terytorialnego, } \\
\text { Narodowa Rada } \\
\text { Zatrudnienia, } \\
\text { Rada Działal- } \\
\text { ności Pożytku } \\
\text { Publicznego } \\
\text { Kongresie Władz } \\
\text { Lokalnych i Re- } \\
\text { gionalnych Eu- } \\
\text { ropy (CLRAE) } \\
\text { Komitet Regio- } \\
\text { nów UE }\end{array}$ & $\begin{array}{l}\text { Komisja } \\
\text { Wspólna Rządu } \\
\text { i Samorządu } \\
\text { Terytorialne- } \\
\text { go; Komitet } \\
\text { Regionów; } \\
\text { Kongres Władz } \\
\text { Lokalnych } \\
\text { i Regionalnych; } \\
\text { współpraca } \\
\text { z biurami } \\
\text { regionalnym } \\
\text { samorządów } \\
\text { polskich }\end{array}$ & $\begin{array}{l}\text { Komisja } \\
\text { Wspólna } \\
\text { Rządu } \\
\text { i Samo- } \\
\text { rządu } \\
\text { Terytorial- } \\
\text { nego }\end{array}$ & $\begin{array}{l}\text { Komisja } \\
\text { Wspólna } \\
\text { Rządu } \\
\text { i Samorzą- } \\
\text { du Teryto- } \\
\text { rialnego, } \\
\text { Komitet } \\
\text { Regionów, } \\
\text { Kongres } \\
\text { Władz } \\
\text { Lokalnych } \\
\text { i Regional- } \\
\text { nych RE, } \\
\text { doraźnie } \\
\text { Parlament }\end{array}$ \\
\hline Skladka & $\begin{array}{l}0,25 \mathrm{zl} \text { od mieszkańca } \\
\text { (system ulg); } 8 \mathrm{mln} \\
\text { składek, }\end{array}$ & $\begin{array}{l}127 \text { tys. od miasta } \\
\text { członkowskiego }\end{array}$ & $\begin{array}{l}2 \text { tys. złotych od } \\
\text { członka }\end{array}$ & $\begin{array}{l}0,035 \mathrm{zl} \text { od } \\
\text { mieszkańca } \\
\text { regionu }\end{array}$ & $\begin{array}{l}\text { Składka } \\
0,14 \text { zł od } \\
\text { miesz- } \\
\text { kańca/ } 4,7 \\
\text { mln na } \\
2015 \text { rok. } \\
80 \% \text { to } \\
\text { składki }\end{array}$ & $\begin{array}{l}\text { Składka } \\
0,3101 \\
\text { zł od } \\
\text { mieszkańca }\end{array}$ \\
\hline
\end{tabular}

Źródło: opracowanie własne.

\section{Zasoby ogólnopolskich organizacji samorządowych}

Przedstawione powyżej zestawienie dokumentów statutowych ogólnopolskich organizacji samorządowych ukazuje duże zróżnicowanie posiadanych zasobów oraz zakresu działach tychże organizacji. Najbardziej rozbudowaną organizacyjnie korporacją jest Związek Miast Polskich, w którym pracuje blisko 30 pracowników administracyjnych obsługujących członków organizacji pod kątem badań i analiz, dostępu do wiedzy na temat bieżących prac legislacyjnych, czy też możliwości udziału w projektach międzynarodowych finansowanych ze środków zewnętrznych. Kolejnymi organizacjami są Unia Metropolii Polskich, Związek Województw RP i Związek Powiatów Polskich. Z kolei organizacją, która ma najmniejsze zasoby jest Unia Miasteczek Polskich.

Najczęściej poruszanymi zagadnieniami, na których koncentrują się w swoich pracach ogólnopolskiej organizacje samorządowe są sprawy związane 
z promowanie idei samorządu terytorialnego. Z praktyki ich funkcjonowania widać, że jest to kwestia towarzysząca w zasadzie wszystkim podejmowanym inicjatywom, w związku z tym należy je rozumieć jako wspólny mianownik wskazanych organizacji. Kolejnymi zagadnieniami jest z kolei wymiana dobrych praktyk oraz wspólne występowanie w obronie interesów samorządów zrzeszonych w określonych organizacjach. Można zatem stwierdzić, że wskazane zagadnienia stanowią w zasadzie sedno ich funkcjonowania i z pewnością najważniejszą zachętę dla samorządów przystępujących do organizacji samorządowych.

Tabela 2. Zakres promowanych kwestii przez ogólnopolskie organizacje samorządowe.

\begin{tabular}{|l|c|}
\hline \multicolumn{1}{|c|}{ Zakres tematyczny } & \multicolumn{1}{|c|}{$\begin{array}{c}\text { Liczba korporacji } \\
\text { samorządowych }\end{array}$} \\
\hline Promowanie idei samorządu terytorialnego & 6 \\
\hline Propagowanie wymiany doświadczeń & 4 \\
\hline Obrona wspólnych interesów & 3 \\
\hline $\begin{array}{l}\text { Współpraca z organami państwa i innymi organiza- } \\
\text { cjami międzynarodowymi }\end{array}$ & 3 \\
\hline
\end{tabular}

Źródło: Opracowanie własne na podstawie analizy dokumentów statutowych.

Analizując sposoby działania ogólnopolskich organizacji samorządowych można zauważyć wiele podobieństw w tej kwestii, co wynika z pewnością $\mathrm{z}$ bardzo zbliżonego obszaru aktywności tychże organizacji. Co istotne, we wszystkich organizacjach samorządowych powszechnym sposobem działania jest przygotowywanie stanowisk wobec projektów aktów prawnych, a także przeprowadzanie badań, analiz i ekspertyz związanych z problematyką funkcjonowania jednostek samorządowych. Oznacza to, że organizacje samorządowe główny nacisk w swojej działalności kładą na sprawy legislacyjne i przenoszenie stanowisk i opinii członków swoich organizacji na forum krajowym. Są one zatem pośrednikiem pomiędzy interesami jednostek samorządu terytorialnego, a podmiotami administracji rządowej.

Tabela 3. Sposoby działania ogólnopolskich organizacji samorządowych.

\begin{tabular}{|l|c|}
\hline \multicolumn{1}{|c|}{ Zakres tematyczny } & Liczba korporacji samorządowych \\
\hline Stanowiska wobec projektów aktów prawnych & 6 \\
\hline Badania, analizy, ekspertyzy & 6 \\
\hline Szkolenia, działalność doradcza & 4 \\
\hline Lobbing legislacyjny & 2 \\
\hline
\end{tabular}

Źródło: Opracowanie własne na podstawie analizy dokumentów statutowych. 
Analiza funkcjonowania ogólnopolskich organizacji samorządowych wskazuje również, że reprezentujące w relacjach rządowo-samorządowych ogólnopolskie organizacje samorządowe mają utrwaloną pozycję. W przypadku reprezentacji jednostek samorządu gminnego funkcjonują one bowiem nieprzerwalnie od początku lat 90., często odwołując się do dorobku organizacji z okresu międzywojennego, co można zauważyć w szczególności w przypadku Związku Miast Polskich oraz Związku Gmin Wiejskich RP. Jak zauważa J. Piasecki: „Tworzenie samorządowych reprezentacji było wynikiem dążeń lokalnych elit do wzmocnienia swej pozycji w polskich życiu publicznym. Rola tych struktur polegała nie tylko na reprezentacji i lobbingu na rzecz samorządu. Dzięki nim wielu działaczy lokalny mogło zaistnieć na krajowej scenie polityczne, natomiast we własnych środowiskach stowarzyszenia te stały się ważnym przewodnikiem na drodze do demokracji, samokształcenia i samorządności"13.

Jednostki samorządowe stopnia powiatowego i wojewódzkiego posiadają z kolei swoją reprezentację od czasu utworzenia tegoż stopnia w strukturze samorządu terytorialnego w Polsce, tj. od czasu reformy z 1999 roku. Wskazany czynnik z pewnością sprzyja systematyczne instytucjonalizacji reprezentacji samorządowej w ramach prac Komisji Wspólnej Rządu i Samorządu Terytorialnego, a także wypracowaniu zasad współpracy nieformalnej, która jest trudna do uchwycenia i zbadania w ramach badań dokumentów i regulacji prawnych, a z pewnością stanowi istotny element negocjacji obu stron i prowadzenia systematycznego dialogu.

$\mathrm{Z}$ całą pewnością zagadnieniem problematycznym w relacjach rządowo-samorządowych jest kwestia niewielkiej reprezentacji jednostek samorządu terytorialnego przez ogólnopolskie organizacje samorządowe. Jedynie 50\% jednostek samorządu terytorialnego nie jest członkami żadnej z ogólnokrajowych korporacji samorządowych. Należy zatem stwierdzić, że organizacje te nie stanowią ogólnopolskiej reprezentacji krajowej jednostek samorządu terytorialnego, a jedynie jest znaczącej części. Trudno jednoznacznie stwierdzić jakie są powody nie przystępowania do wskazanych zrzeszeń pozostałych samorządów. Czy przyczyną są bariery natury finansowej (składka członkowska), czy może niedostrzeganie potencjalnych korzyści z takiego członkostwa? Faktem jednak jest to, że blisko połowa jednostek samorządowych nie należy do żadnej organizacji tego typu, tym samym pozbawiona jest dostępu do wiedzy na temat

13 A.J. Piasecki, Samorząd terytorialny i wspólnoty lokalne, Warszawa 2009, s. 221. 
dobrych praktyk w realizacji zadań publicznych, bądź bieżącej informacji na temat planowanych zmian prawnych i wypowiadania się na ten temat. Problem stworzenia odpowiedniej reprezentacji jednostek samorządu terytorialnego na szczeblu ogólnokrajowym znany jest niemalże od początku funkcjonowania odrodzonego samorządu. Pierwotny senacki projekt ustawy o samorządzie terytorialnym przewidywał bowiem utworzenie obligatoryjnej reprezentacji gmin w skali kraju. Jak zauważył J. Regulski potrzeba utworzenia ogólnopolskiego stowarzyszenia gmin jako podmiotu w relacjach rządowo-samorządowych zgłaszana była już w czasie prac studialnych w latach 80., kiedy opowiadano się za zestytucją Związku Miast Polskich. Propozycja ta została odrzucona w czasie prac sejmowych przez posłów z klubu PZPR, którzy przekonali część parlamentarzystów, że byłaby to „czapa” nad samorządami gminnymi. Kolejną taką próbę legislacyjną miał podjąć poseł W. Pańko w końcu lat 1990. Jego propozycje nie znalazły jednak wystarczającego poparcia w Sejmie ${ }^{14}$. Z perspektywy obecnie obowiązującej Konstytucji RP i przysługującego na jej mocy konstytucyjnego prawa swobody zrzeszania się jednostek samorządu terytorialnego do zrzeszeń ogólnopolskich oraz międzynarodowych, utworzenie obligatoryjnej reprezentacji samorządowej jest niemożliwe. Jak zauważa B. Dolnicki współdziałanie podejmowane przez jednostki samorządu terytorialnego ma charakter dobrowolny. Oznacza to swobodę w wyborze formy współdziałania, swobodę tworzenia i likwidacji form współdziałania ${ }^{15}$. Tym nie mniej cały czas trzeba jednak pamiętać o istotnym deficycie współpracy samorządowej, z którym mamy do czynienia na poziomie zaangażowania jednostek samorządu terytorialnego w relacje rządowo-samorządowe.

Analizując potencjał organizacji samorządowych warto zwrócić uwagę na fakt, że zasoby organizacyjne oraz kadrowe do prowadzenie systematycznych działań posiada jedynie Związek Miast Polskich, Związek Powiatów Polskich oraz częściowo w zakresie miast Unia Metropolii Polskich i Związek Województw RP. Wynika to z dwóch powodów. W przypadku pierwszej grupy organizacji (ZMP i ZPP) potencjał organizacji jest wynikiem sporej bazy członkowskiej, która w połączeniu z systematycznym wsparciem finansowym (składki członkowskie samorządów) umożliwia zbudowanie zaplecza organizacyjnego oraz kadrowego. Inaczej z kolei wygląda to w przypadku drugiej grupy organizacji (UMP i ZWRP). W tym przypadku liczba samorządów - członków

14 Zob. szerzej: J. Regulski, Samorzad III Rzeczpospolitej. Koncepcja i realizacja, Warszawa 2000 r., s. 6.

15 B. Dolnicki, Samorząd terytorialny, Warszawa 2009, s. 258.

\section{6}


organizacji samorządowych jest niewielka, jednak dzięki reprezentacji dużych i przez to zasobnych jednostek samorządu terytorialnego są duże składki członkowskie (szczegóły patrz w Tab. 1.). Dzięki temu organizacje te są w stanie powołać samodzielne zaplecze organizacyjne. W związku z brakiem obu ww. czynników w przypadku Unii Miasteczek Polskich oraz Związku Gmin Wiejskiej RP - organizacje te poza przenoszeniem stanowisk swoich członków na poziom krajowy i systematycznym uczestnictwie w pracach Komisji Wspólnej Rządu i Samorządu Terytorialnego, nie gwarantują żadnej wartości dodanej.

\section{Uwagi końcowe}

Ogólnopolskie organizacje samorządowe stanowią reprezentację 50\% jednostek samorządu terytorialnego funkcjonujących w Polsce. Największą reprezentację mają samorządy stopnia wojewódzkiego (wszystkie regiony należą do Związku Województw RP), a następnie samorządy powiatowe. Jednostki samorządu terytorialnego stopnia gminnego mają najmniejszą reprezentację, przy czym największy deficyt występuje w przypadku gmin wiejsko-miejskich, które zrzesza Unia Miasteczek Polskich. Tak zróżnicowana struktura reprezentacji wpływa na możliwości finansowe i kadrowe, które posiadają ww. organizacje. Na podstawie analizy ich działalności można stwierdzić, że są to organizacje, które w głównej mierze działają „do środka”, tzn. na rzecz swoich członków. Trudno im bowiem znaleźć wspólne interesy i wprowadzić na agendę polityczną wspólny projekt zmian. Wyjątkiem jest obywatelski projekt ustawy o zmianie ustawy o dochodach jednostek samorządu terytorialnego, który przedstawiony został jako „Stawka większa niż 8 mld”16. Jest to zapewne

16 Projekt Stawka większa niż 8 mld to akcja korporacji samorządowych, które zmierzała do zebrania podpisów pod obywatelskim projektem ustawy o zmianie ustawy o dochodach jednostek samorządu terytorialnego, który zakładał zwiększenie udziału jednostek samorządu terytorialnego wszystkich stopni w podatkach dochodowych PIT i CIT przekazywanych do budżetów lokalnych i regionalnych. Projekt ustawy jest obecnie po pierwszych czytaniu w Sejmie. Warto jednak zwrócić uwagę, że istnieją także inne poza finansowymi, motywy wspólnego działania ogólnopolskich organizacji samorządowych. Przykładem jest tutaj wspólny apel pięciu korporacji samorządowych przeciwko centralizacji państwa (Porozumienie Związku Województw RP, Związku Miast Polskich, Unii Miasteczek Polskich, Związku Gmin Wiejskich RP, Związku Powiatów Polskich przyjęte w trakcie Konwentu Marszałków RP w dniu 3 sierpnia 2016 r. w Szczecinie). Jak zauważają w nim samorządowcy budowana od 27 lat samorządność jest uznawana za jedno z największych osiągnięć polskiej transformacji. Ich zdaniem ostatnio obserwowane są tendencje 
wynikiem dużego zróżnicowania demograficznego, gospodarczego, a przez to finansowego jednostek samorządu terytorialnego, które ma swoje konsekwencje w sposobie działania ogólnopolskich organizacji samorządowych. W konsekwencji organizacje samorządowe występują głównie w formie pośredników interesów politycznych swoich członków, którzy to za pomocą organizacji samorządowych próbują znaleźć dojście do procesu decyzyjnego i wywrzeć wpływ na treść decyzji politycznych podejmowanych zazwyczaj w formie procesu legislacyjnego. Korporacje samorządowe pełnią zatem ważną rolę integrującą, są swoistym zwornikiem interesów określonych grup jednostek samorządowych. Najważniejszym dojściem do strategicznych ośrodków władzy stanowi Komisja Wspólna Rządu i Samorządu Terytorialnego.

\section{Literatura}

1. Dolnicki B., Samorzad terytorialny, Wolters Kluwer, Warszawa 2009.

2. Gawłowski R., Komisja Wspólna Rządu i Samorządu Terytorialnego-od konsultacji do wspótudziału w rządowym procesie legislacyjnym, „Samorząd Terytorialny” 2015, nr 12, s. $5-15$.

3. Herbut R., Interes polityczny - proces instytucjonalizacji grup polityki grup interesu oraz jej modele, [w:] B. Szmulik, M. Żmigrodzki (red.), Wprowadzenie do nauki o państwie i polityce, Wydawnictwo UMCS, Lublin 2007.

4. Mette Kjær A., Governance, Polity Press, Cambridge 2004.

5. Morphet J., Modern Local Government, Sage Publication, California 2008.

6. Piasecki A.J., Samorząd terytorialny i wspólnoty lokalne, Wydawnictwo Naukowe PWN, Warszawa 2009.

7. Rajca L., Reformy inspirowane koncepcja wspótrządzenia (governance) w Anglii, [w:] D. Plecka (red.), Wspótczesne wyzwania administracji rzadowej i samorzadowej, Wydawnictwo Adam Marszałek, Toruń 2013.

8. Regulski J., Samorzad III Rzeczpospolitej. Koncepcja i realizacja, PWN, Warszawa 2000.

9. Sroka J., Deliberacja i rzadzenie wielopasmowe. Teoria i praktyka, Wydawnictwo Uniwersytetu Wrocławskiego, Wrocław 2009.

Robert Gawłowski

Wyższa Szkoła Bankowa w Toruniu Wydział Finansów i Zarządzania w Bydgoszczy

do centralizacji państwa. Deklaracja ma na celu wzmocnienie głosu samorządów różnych szczebli w rozmowach z rządem, gdyż to właśnie samorząd powinien być najważniejszym ogniwem $\mathrm{w}$ procesie dialogu. 